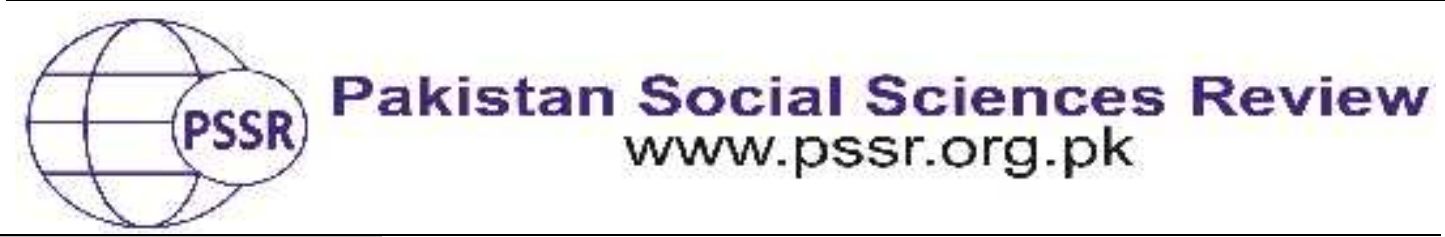

RESEARCH PAPER

\title{
Contribution of Agri-Inputs to Rural Poverty Mitigation: A Village Study
}

\author{
Muhammad Zahir Faridi* 1 Ali Azam ${ }^{2}$ Maria Sajjad Khan ${ }^{3}$
}

1. Professor, School of Economics, Bahauddin Zakariya University, Multan, Punjab, Pakistan

2. Assistant Professor, Department of Economics, The Islamia University of Bahawalpur, Punjab, Pakistan

3. M. Phil Scholar, School of Economics, Bahauddin Zakariya University, Multan, Punjab, Pakistan

\begin{tabular}{|c|c|}
\hline PAT & \\
\hline $\begin{array}{l}\text { d: } \\
2021 \\
021 \\
021\end{array}$ & $\begin{array}{l}\text { Poverty becomes a chronic issue in develop } \\
\text { especially in rural areas. The present study is about } \\
\text { considering the role of agricultural inputs like fe } \\
\text { holding, live stocks and tractor. The study is } \\
\text { primary source of data. Two hundred fifty hou }\end{array}$ \\
\hline $\begin{array}{l}\text { ds: } \\
\text { cy Ratio, } \\
\text { tus, } \\
\text { dholdings } \\
\text { ctor }\end{array}$ & $\begin{array}{l}\text { interviewed. Logistic regression tech } \\
\text { explore the effects of Agri-related fa } \\
\text { economic factors on rural poverty. The } \\
\text { variables like fertilizers, land holdings, } \\
\text { education of the farmer, good healt }\end{array}$ \\
\hline ponding & $\begin{array}{l}\text { overty. It is suggested that the government should provide the } \\
\text { rtilizer at cheaper rate and facilitate use of tractor in } \\
\text { dltivation. }\end{array}$ \\
\hline
\end{tabular}

\section{Introduction}

These are certain factors that differentiate the economies with each other's. The world's economy is divided among developed nations, developing countries, underdeveloped economies, poor economies, and emerging economies. But there are some common issues prevailing in these poor and underdeveloped countries like poverty unemployment inflation, budget deficit, current deficit etc. Although intensity of these issues differ but more or less each country is facing these problems. Pakistan's economy is neither developed nor poor. She is also facing the issues of unemployment, poverty, inflating, low growth rate, rising population etc. According to Rostow stages of growth, economies passe through the five stage of growth. The critical stage is takeoff, but Pakistan is passing through the stage of precondition for takeoff. 
The present study focuses on the issue of poverty. This issue has become a challenge for the economy like Pakistan. The problem becomes more severe due to covid-19. Economic activities are disturbed due to fall in domestic and international demand, decline in tourism and business travel and supply distortion. The GDP growth rate is recorded -0.38 percent. The growth rates of industrial and services sectors are remained -2.64 and -0.59 percent respectively during the financial year 2020. While agricultural growth rate is estimated 2.67 percent. Livestock sector has attained growth rate 2.58 percent while fishing and forestry sectors have achieved growth rates 0.60 percent and 2.29 percent respectively. Although, agricultural sector growth rate indicates the best performance but rising population high unemployment especially in young make the economy's condition worse and aggravates the poverty particularly in rural area where almost 60 percent population is residing. The projected population for the year 2019 is 211.1 million and population density is measured 265 per $\mathrm{Km}$. The unemployment rate is recorded 5.8 percent and youth unemployment $(20-24$ age $)$ is recorded 11.56 percent that is the at highest level. Moreover, the covid-19 pandemic has adversely affected the employment generation. These all facts become the cause of overall poverty, but rural poverty become more dangerous, in Pakistan (GOP. Economic Survey 2020).

The main objective of the present study is to analyze the impact of agricultural inputs on rural poverty. The rest of the research paper is arranged as follows. The first section provides the introduction with highlighting the research problem. Some relevant and important studies are reviewed in the second section. The third section discusses the data sources and methodological issues. The findings are elaborated in the fourth section. Lastly the concluding remarks and policy recommendation are summarized.

\section{Literature Review}

A lot of research is available on the topic of poverty at national level or at the international level in the literature. Some current studies relevant to poverty and agrarian economy are reviewed. Jhon et al. (1999) discussed the effect of agricultural research and improved technology for poverty reduction in underdeveloped economies. They had studied the partial and indirect impact of technology to mitigate poverty. Moreover, other socio-economic and institutional factors were explained that were responsible for poverty alleviation. Irz et al (2001) explained the link between agricultural productivity growth and poverty alleviation. They developed the cross-country link between agricultural yield per unit and rural poverty. The findings revealed that the linkages from agriculture production to poverty operated significantly. Moreover, the study concluded that labour productivity and land-labour ratio alleviate the poverty.

Talat et al. (2004) analyzed the socio-economic status of the farmers who were facing the issues of poverty in rural area. They explained that rural poverty continuously increased during the decade 1990's. The study concluded that lack of land and lands less people were very poor. The authors suggested that by reducing 
landownership inequalities and raising agricultural productivity, poverty may be reduced. Other inputs like water availability, seeds, fertilizers, credit facilities and agricultural research had significant role in poverty reduction.

Hussain and Hanjra (2004) developed the association between poverty and irrigation development. They explained the anti-poverty impacts of irrigation and traced the direct and indirect linkages between poverty and irrigation. The findings showed that the irrigation provided benefits to the poor through higher production, lower risk of crop failure, higher yield and more farm employment. Swallow, B. (2005) conducted a research for rural poverty reduction through poverty alleviation strategies. He examined thatby provision of the most transport delivery of public services program to rural area caused poverty alleviation. He concluded that the major causes ofruralpoverty were livestock diseases and production water and sanitation, human diseases, soil degradation etc.

Christiaensen et al. (2006) analyzed the effects of agricultural related factors on poverty reduction. The findings showed that the increasing agricultural productivity, agricultural technology and investment reduced the poverty. Bhutto and Bazmi (2007) examined the facts of poverty in rural areas in Pakistan. They concluded that increased population, decreasing land for cultivation and farming increased the poverty. It is suggested that use of pesticides, fertilizer, tractor, harvester and better irrigation facilities had become the cause of poverty.

Dahal et al. (2007) concluded and suggested that the agricultural intensification through rapid utilization of fertilizer improved the living standard, livelihood and income opportunities for rural people. Hussain (2005) analyzed the influence of agriculture growth on poverty alleviation. Azuh and Matthew (2010) discussed role of agricultural sector on poverty alleviation and rising economic growth. Fertilizer distribution and agricultural export turned out to be the most significant factors. Ali and Abdulai (2010) examined the effect of using Bacillus thuringiensis (BT) on production of cotton. They emphasized that the use of new technology and BT cotton variety seed had raised the productivity, improved the farmers' status by reducing poverty level. Brown and Kennedy (2005) diagnosed that agriculture commercialization were considered as a mechanization for alleviating poverty.

Ahmed and Heng (2012) examined that agricultural productivity ensured the food security. They have estimated long-run and short-run elasticities for fertilizers Agri credit and cropped area. Keil et al. (2013) investigated that the use of intensive commercial agriculture method reduced the poverty and ensured the sustainable environment. The rural credit becomes necessary for rural development. Corral et al. (2017) studied the agricultural policies for poverty elimination in developing economies. The findings showed that the construction of water storage, water distribution infrastructure, strengthens drip irrigation and farmers' training raised farmers' performance and reduced the poverty. Ezeomedo and Egware (2018) explored that extreme poverty was reduced by developed agricultural sector. They found positive relationship between agricultural inputs and agricultural 
productivity. Hayat et el. (2019) examined the role of agrarian economy in reducing poverty. They concluded that agricultural growth, cash crops, livestock, fisheries, and forestry were significantly caused poverty alleviation. Arsyad et al. (2020) discussed the role of public health services in reducing rural poverty. Findings revealed that easy or better access to public health services decreased the health cost of households and reduced poverty.

\section{Material and Methods}

Information about data collection sources, operational definitions of relevant variables and measurement issues are explained.

\section{Data Sources}

The study is based on the primary sources of data. Some villages of district Rajanpur, the main district of the Southern Punjab is selected for exploring the facts of rural poverty. Simple random sampling technique is used to draw the sample. A simple and comprehensive questionnaire is constructed to collect the information 250 respondents selected based on systematic sampling technique are interviewed and information are recorded at the spot. Poverty status of the respondent is gauged using the international poverty line i.e. 1.25\$ per day per person. Data about other socio-economic variables are gathered except Agri-related variables in order to make the analysis realistic.

\section{Methodological issues}

The regress end variable in our model is poverty that is qualitative or binary in nature. It shows the presence or absence and takes the value one for poor and zero for non-poor. The Binary Logistic technique is appropriate for estimating the parameters of the variables.

The cumulative Logistic distribution function is given by

$$
\begin{aligned}
& P_{i}=\frac{1}{1+e^{-y i}}=\frac{e^{y}}{1+e^{y}} \\
& \text { Where } Y_{i}=\beta_{o}+\beta_{1} X_{1 i}+\beta_{2} X_{2 i}+---+\beta_{k} X_{k i}+\mu_{i}
\end{aligned}
$$

If $\mathrm{Pi}$ is the probability of being poor, then the probability of being non-poor is

$$
\begin{aligned}
1-P_{i}= & \frac{1}{1+e_{Y i}} \\
& \left(\frac{P_{i}}{1-P_{i}}\right)=\frac{1+e^{Y i}}{1+e^{-Y i}}=e^{Y i}
\end{aligned}
$$




$$
L i=\ln \left(\frac{P i}{1-P i}\right)=Y i=\beta_{o}+\beta_{1} X_{1 i}+\beta_{2} X_{2 i}+---+\beta_{k} X_{k i}+\mu_{i}
$$

\section{Operational Model}

The poverty model based on the operational definitions of the variables is given in the following functional forms.

$$
\begin{aligned}
\text { Pov }=f(E X P, E X P 2, E D Y, F M S, S E X, M S T, H L T, D P R, H O C, I F S, & \\
& N L S, L H D, F R L, T R T) \\
\text { Pov }= & \beta_{o}+\beta_{1} E X P+\beta_{2} E X P^{2}+\beta_{3} E D Y+\beta_{4} F M S+\beta_{5} S E X+\beta_{6} M S T+\beta_{7} H L T+ \\
& \beta_{8} D P R+\beta_{9} H O C+\beta_{10} I F S+\beta_{11} N L S+\beta_{12} L H D+\beta_{13} F R L+\beta_{14} T R T+\mu i
\end{aligned}
$$

\begin{tabular}{|c|c|c|}
\hline Variables & Description & Expected Sign \\
\hline Pov & $\begin{array}{l}\text { Poverty status of the household of the farmers' } \\
\text { community. It is dummy variable. It is one if Farmer } \\
\text { is being poor and "0" otherwise. It is measured by } \\
\text { international poverty line } \$ 1.25 \text { per day per person. }\end{array}$ & - \\
\hline $\operatorname{Exp}$ & $\begin{array}{l}\text { Experience: it shows the experience of the farmers. It } \\
\text { is calculated by Experience = Age }- \text { Education }-5 \text {. }\end{array}$ & Negative \\
\hline Exp2 & $\begin{array}{l}\text { Experience squared. It is used to examine the } \\
\text { nonlinearity effect. }\end{array}$ & Negative \\
\hline EDY & Education: in completed year of education. & Negative \\
\hline FMS & $\begin{array}{l}\text { Family system or family set up. It is dummy variables. } \\
\text { " } 1 \text { " if the joint family system prevails, otherwise " } 0 \text { " }\end{array}$ & Positive \\
\hline SEX & $\begin{array}{l}\text { Sex explains the gender i.e. male or female " } 1 \text { " if male, } \\
\text { " } 0 \text { " otherwise }\end{array}$ & Negative \\
\hline MST & $\begin{array}{l}\text { Marital status. " } 1 \text { " if the household is married, " } 0 \text { " } \\
\text { otherwise }\end{array}$ & Negative \\
\hline HLT & $\begin{array}{l}\text { Health status of rural household or farmer. It is also } \\
\text { binary variable " } 1 \text { " if the farmer or household health } \\
\text { is better, " } 0 \text { " otherwise }\end{array}$ & Negative \\
\hline \multirow[t]{2}{*}{ DPR } & \multirow{2}{*}{$\begin{array}{l}\text { Dependency ratio. It is calculated by the formula. } \\
D P R=\frac{\text { Childernbelow } 15 \text { year }+ \text { old age above } 60 \text { year }}{\text { Total Family size }}\end{array}$} & \multirow[t]{2}{*}{ Positive } \\
\hline & & \\
\hline $\mathrm{HOC}$ & $\begin{array}{l}\text { House condition of farmer. It calculated by dummy } \\
\text { variables " } 1 \text { " if house Kacha or made of mud and } \\
\text { grass, " } 0 \text { " otherwise. }\end{array}$ & Positive \\
\hline IFS & Infrastructure includes road, schools, hospitals, power & Negative \\
\hline
\end{tabular}

The variables given in the operational model are described with their measurement and expected sign the table 1.

Table 1

Variable Description, Measurement, and Expected Sign 
supplies, transport, communication, sewerage facilities etc. we have used dummy variables to show their availability " 1 " if these facilities are available, " 0 " otherwise.

\begin{tabular}{clll}
\hline NLS & $\begin{array}{l}\text { No. of live stocks possessed by household. It is } \\
\text { quantitative variable. }\end{array}$ & Negative \\
\hline LHD & $\begin{array}{l}\text { Landholding by the household in Acres } \\
\text { FRL }\end{array}$ & $\begin{array}{l}\text { Use of fertilizer by the households. It is dummy } \\
\text { variable. "1" if household being farmer use fertilizer } \\
\text { "0" otherwise. }\end{array}$ & Negative \\
\hline TRT & $\begin{array}{l}\text { It is qualitative variable use of tractor by the } \\
\text { household. " } 1 \text { " if household use tractor "0" otherwise. }\end{array}$ & Negative \\
\hline
\end{tabular}

\section{Results and Discussion}

Now, we explain the findings of the research. The discussion is made at two stage level. First of all, we give the explanation of descriptive statistics and degree of association among the variable. In the second stage, we discuss the findings of poverty model based on Logit model.

\section{Descriptive Analysis}

Table 2 explains the summary statistics of some selected variables. We have provided only mean and standard deviations of the variables.

Table 2

Descriptive Statistics of Variables

\begin{tabular}{ccc}
\hline Variables & Mean Values & Standard deviation \\
\hline EXP & 9.88 & 6.537 \\
\hline EDY & 6.524 & 3.5004 \\
\hline SEX & 0.5320 & 0.5010 \\
\hline MST & 0.7360 & 0.4416 \\
\hline HLT & 0.5800 & 0.4979 \\
\hline DPR & 5.7900 & 1.7530 \\
\hline HOC & 0.3280 & 0.4704 \\
\hline IFS & 0.2040 & 0.4037 \\
\hline NLS & 1.1960 & 1.3612 \\
\hline LHD & 2.3000 & 1.4900 \\
\hline FRL & 0.5100 & 0.5020 \\
\hline TRT & 0.4640 & 0.4997
\end{tabular}

The mean value of experience is 9.88 and its variability about mean is 6.537. The year of education on the average is 6.524 with standard deviation 3.50. We have observed that the average values of the variables SEX, MST, and HLT are 0.5320, 0.7360 and 0.58 with their standard deviation values $0.5010,0.4416$ and 0.4979 
respectively. The mean values of dependency ratio, House condition and the availability of infrastructure facilities are 5.79, 0.33 and 0.204 respectively. On the average the household possession of livestock and land holdings are 1.20 and 2.30 with dispersion values 1.36 and 1.49 respectively. The average value of the use of fertilizers and tractor are 0.51 and 0.4640 respectively.

Table 3

Pairwise Correlation Matrix

\begin{tabular}{|c|c|c|c|c|c|c|c|c|c|c|c|c|}
\hline & NLS & EDY & EXP & FMS & FRL & LHD & MST & SEX & TRT & HLT & HOC & IFS \\
\hline NLS & 1 & & & & & & & & & & & \\
\hline EDY & 0.04 & 1 & & & & & & & & & & \\
\hline EXP & 0.07 & -0.04 & 1 & & & & & & & & & \\
\hline FMS & 0.09 & 0.03 & 0.08 & 1 & & & & & & & & \\
\hline FRL & 0.00 & 0.06 & -0.10 & 0.00 & 1 & & & & & & & \\
\hline LHD & -0.24 & 0.27 & -0.01 & 0.05 & 0.09 & 1 & & & & & & \\
\hline MST & 0.03 & -0.02 & 0.04 & 0.32 & 0.05 & 0.15 & 1 & & & & & \\
\hline SEX & 0.04 & 0.07 & -0.03 & 0.16 & 0.17 & 0.20 & 0.06 & 1 & & & & \\
\hline TRT & 0.03 & 0.16 & -0.10 & 0.02 & 0.09 & 0.19 & 0.03 & 0.06 & 1 & & & \\
\hline HLT & 0.06 & 0.08 & -0.13 & 0.13 & 0.14 & 0.26 & 0.06 & 0.09 & 0.09 & 1 & & \\
\hline HOC & -0.03 & -0.13 & 0.01 & -0.08 & -0.08 & -0.03 & 0.03 & 0.00 & 0.03 & 0.11 & 1 & \\
\hline IFS & 0.01 & 0.18 & -0.05 & 0.00 & 0.11 & 0.33 & 0.01 & 0.04 & 0.24 & 0.08 & 0.00 & 1 \\
\hline
\end{tabular}

The table 3 discusses the degree of association among the selected variables. The correlation matrix explains there is no any sign of multicollinearity among the explanatory variables.

\section{Econometric Analysis}

Now, we discuss the findings of rural poverty model based on the logistic regression estimate in table 4

Table 4

Logistic Regression Estimates of the Poverty

\begin{tabular}{ccccc}
\hline Variables & Coefficients & Std. Error & Z-Statistics & Prob. \\
\hline C & 5.377 & 1.153 & 4.67 & 0.000 \\
\hline Exp & -0.129 & 0.0789 & -1.64 & 0.091 \\
\hline Exp2 & 0.00074 & 0.0001 & 0.739 & 0.4601 \\
\hline EDY & -1.183 & 0.4121 & -2.87 & 0.0041 \\
\hline FMS & 0.1103 & 0.1273 & 0.866 & 0.3863 \\
\hline SEX & -0.6348 & 0.3984 & -1.593 & 0.1011 \\
\hline MST & -1.133 & 0.516 & -2.193 & 0.0283 \\
\hline HLT & -1.851 & 0.5007 & -3.697 & 0.0002 \\
\hline
\end{tabular}




\begin{tabular}{|c|c|c|c|c|}
\hline DPR & 0.3024 & 0.1476 & 2.049 & 0.041 \\
\hline $\mathrm{HOC}$ & 0.2636 & 0.4441 & 0.594 & 0.553 \\
\hline IFS & -0.222 & 0.4051 & -0.548 & 0.584 \\
\hline NLS & -1.486 & 0.4312 & -3.446 & 0.0002 \\
\hline LHD & -1.255 & 0.4245 & -2.956 & 0.0031 \\
\hline FRL & -1.793 & 0.4626 & -3.879 & 0.0001 \\
\hline TRT & -1.257 & 0.4218 & -2.9801 & 0.0029 \\
\hline MC Fadden $\mathrm{R}^{2}$ & 0.458 & & LR Statistic & 150.286 \\
\hline Log likelihood & -163.921 & & $\begin{array}{l}\text { Probability (LR } \\
\text { statistics) }\end{array}$ & 0.000 \\
\hline
\end{tabular}

The LR statistics explains the overall significance level. The coefficient of LR statistics is highly significant and guarantees the overall significance and good fitted of the model. The value of MC Fadden $\mathrm{R}^{2}$ is 0.458 .We have noted that the Coefficient of experience is negative and statistically significant. It means that the rural households are less likely to be poor if there is an increase of one year of experience of rural people in farming. The reason may be that the farm production increases, and rural people become well off. The experience squared terms used to examine the non-linearity influence. The coefficient of experience square is positive and insignificant. The finding shows that the education is inversely related to poverty. The poverty status of the rural farming community is likely to be reduced about 1.183 units due to an increase of one year of education. The coefficient of EDY is highly significant. The reason may be that the education is the main source of raising earnings of the households by increasing skills, income, and employment opportunities. The results are stay in line with the findings of Sharma et al. (2011). It is observed that the family setup has positive and insignificant impact on rural poverty. The finding reveals that joint family system enhances the poverty level.

We have noted that coefficient of SEX is negative and statistically marginally significant. The probability of poverty level is to be decreased, as an increase of one unit of male because male gender is main bread winner. The finding is matched with Komatsu et al. (2019) that more poverty is noted among females. It is found that the household living in rural farming community with better health is less likely to be poor. The probability of poverty reduces significantly about 1.85 units because of healthy households. Healthy people work efficiently, produces more output and income level is increased. Our results are supporting to the study of Javed et al. (2008). The coefficient of marital status (MST) is not only negative, but it is highly significant at one percent level of significance. Married people are less likely to be poor.

We have noted that the coefficient of dependency ratio is positive and highly significant. The rural households are more likely to be poorer due to high dependency ratio. The result of the study shows that an increase of dependency burden leads to more poverty about 0.302 units. Poor house condition turns out to be 
poverty escalator factor. The research outcome shows that the Kacha house or made of mud and grass raises the probability of rural poverty about 0.264 units. The coefficient of the availability of infrastructure (IFS) is negative 0.222 and statistically insignificant. The probability of poverty falls about 0.222 units because of availability of infrastructure facilities like roads hospitals, markets etc.

The core variables of the research paper are number of livestock, size of landholdings, use of fertilizers and tractors. We have found that all Agri-related variables have negative impact on poverty status of the farmers' community. The rural households are less likely to be poor due to having a greater number of live stocks. the probability of rural poverty falls about 1.49 units due to an increase of one unit in livestock. The reason may be that in rural areas, the live stocks are main source of income generation and become the cause of poverty reduction. Our findings are corroborating with the results of Rizwan Ahmad (2013). The coefficient of size of landholdings is negative and statistically highly significant at one percent level. The probability of rural poverty declines about 1.26 units because of more size of landholdings. The big landlords have more opportunities of earnings and they are living above the poverty line. The finding shows that the coefficient of the use of fertilizer is negative and statistically significant. The rural farming community is less likely to be poor if it uses fertilizers immensely. The reason may be that the farm productivity increases and alleviates poverty. It is observed in the present study that the use of mechanization has a significant influence in poverty reduction. The coefficient of use of tractor (TRT) is -1.26 and highly significant. The probability of poverty is reduced about 1.26 units due to an increase of unit of tractor in cultivation. The reason may be that the mechanization raises the productivity at large scale and output of the farmers increase.

\section{Conclusion}

The present study is designed to trace out the impact of agricultural inputs like use of fertilizers, tractors, live stocks, and size of landholdings on rural poverty. The study is based on primary source of data. The study area is selected form rural south Punjab (Rajanpur District). Some other socio-demographic factors i.e., education, experience, health related issues, house condition, gender, and family setup etc are considered in the analysis. The study concludes that experience, education, sex, marital status, health has significant impact. Moreover, it is diagnosed that agricultural related variables significantly reduces poverty in rural areas.

The following suggestions are formulated based on the findings of the study.

i) It is suggested that Government should provide the education facilities especially agricultural related education in rural areas.

ii) Hospitals and rural dispensaries should be established in order to provide the health facilities to the rural community. 
iii) The awareness regarding the use of fertilizer and machinery should be created among the farmers. The fertilizers should be produced at low cost and provided to the farmer at low prices.

iv) Government should optimize the size of landholdings and proper land reforms policies should be formulated.

v) Livestock turns out to be the main source of income in rural areas. Proper guidance should be given to the farmers for increasing the live stocks. Dairy farms and milk products-based industries should be established. 


\section{References}

Ahmad, K., \& Heng, A. C. T. (2012). Determinants of agriculture productivity growth in Pakistan. International Research Journal of Finance and Economics, 95, 163173.

Ahmed, T., Khan, K. S., \& Naeem, M. (2019). The Effect of Public Spending on Agricultural Growth: Evidence from 1972 to 2014 in Pakistan. Sarhad Journal of Agriculture, 35(2), 349-357.

Ali, A., \& Abdulai, A. (2010). The adoption of genetically modified cotton and poverty reduction in Pakistan. Journal of Agricultural Economics, 61(1), 175-192.

Anwar, T., Qureshi, S. K., Ali, H., \& Ahmad, M. (2004). Landlessness and rural poverty in Pakistan [with comments]. The Pakistan Development Review,43(4) 855874.

Arsyad, M., Pulubuhu, D. A. T., Kawamura, Y., Maria, I. L., Dirpan, A., Unde, A. A., \& Yusuf, S. (2020). The role of public health services (PHS) in agricultural poverty alleviation. Enfermeria clinica, 30, 194-197.

Azuh, D. E., \& Matthew, O. (2010). The role of agriculture in poverty alleviation and national development in Nigeria. African Journnal of Economy and Society, 10(1\&2), 17-32.

Bhutto, A. W., \& Bazmi, A. A. (2007, November). Sustainable agriculture and eradication of rural poverty in Pakistan. In Natural Resources Forum 31(4) 253-262 Oxford, UK: Blackwell Publishing Ltd.

Brown, S., \& Kennedy, G. (2005). A case study of cash cropping in Nepal: Poverty alleviation or inequity?. Agriculture and Human Values, 22(1), 105-116.

Christiaensen, L., Demery, L., \& Kuhl, J. (2006). The role of agriculture in poverty reduction an empirical perspective. The World Bank.

Corral, S., Díaz, A. S., Monagas, M. D. C., \& García, E. C. (2017). Agricultural policies and their impact on poverty reduction in developing countries: Lessons learned from three water basins in Cape Verde. Sustainability, 9(10), 1841.

Dahal, B. M., Sitaula, B. K., \& Bajracharya, R. M. (2008). Sustainable agricultural intensification for livelihood and food security in Nepal. Asian Journal of Water, Environment and Pollution, 5(2), 1-12.

Ezeomedo, I. C., \& Egware, R. A. (2018). Eradication Of Extreme Poverty And Hunger Using Urban Agriculture As A Tool For Sustainable Livelihood. African Journal of Environmental Research, 1(1), 78-97.

Govt. of Pakistan (2020). Pakistan Economics Survey, Federal Bureau of Statistics. 
Gujarati, D. N. (1995). Basic Econometrics, 3-rd ed.

Hayat, U., Ali, S., Mateen, A., \& Bilal, H. (2019). The role of agriculture in poverty alleviation: Empirical evidence from Pakistan. Sarhad Journal of Agriculture, 35(4), 1309-1315.

Hussain, A. (2005, April). Agriculture growth and poverty reduction: A policy perspective. In international seminar on management of the Pakistan economy, Lahore School of Economics, Pakistan.

Hussain, I., \& Hanjra, M. A. (2004). Irrigation and poverty alleviation: review of the empirical evidence. Irrigation and drainage, 53(1), 1-15.

Irz, X., Lin, L., Thirtle, C., \& Wiggins, S. (2001). Agricultural productivity growth and poverty alleviation. Development policy review, 19(4), 449-466.

Javed, Z. H., Khilji, B. A., \& Mujahid, M. (2008). Impact of education on socioeconomic status of villagers life: A case study of shrien wala village of faisalabad district. Pakistan Economic and Social Review, 46(2), 133-146.

Keil, A., Saint-Macary, C., \& Zeller, M. (2013). Intensive commercial agriculture in fragile uplands of Vietnam: how to harness its poverty reduction potential while ensuring environmental sustainability?.Quarterly Journal of International Agriculture, 52(892-2016-65176), 1-25.

Kerr, J. M., \& Kolavalli, S. (1999). Impact of agricultural research on poverty alleviation: Conceptual framework with illustrations from the literature.EPTD Discussion Paper No. 56

Komatsu, H., Malapit, H., \& Balagamwala, M. (2019). Gender effects of agricultural cropping work and nutrition status in Tanzania. PloS one, 14(9), 1-17. e0222090.

Rostow, W. W. (1959). The stages of economic growth. The economic history review, 12(1), 1-16.

Sharma, D. K. (2011). Landholding size and educational and occupational status in Two Villages of Dang. Geographical Journal of Nepal, 8, 43-52.

Swallow, B. (2005). Potential for poverty reduction strategies to address community priorities: case study of Kenya. World Development, 33(2), 301-321. 